\title{
INCREASING THE PRODUCTIVITY IN A MAGNESITE PILOT PLANT COMBINING OPEN BALL MILL CIRCUIT AND HIGH FREQUENCY SCREENER
}

\author{
Matheus Naves Moraes ' \\ Paschoal Bonadia Neto ' \\ Paulo Roberto Gomes Brandão ${ }^{2}$
}

\begin{abstract}
Open circuit and high frequency screener have already been adopted by some mining operations, however not taking advantage of its full potential. This work presents a new approach, combining them to have a better use of the available energy and, thus, increasing productivity. This concept could fit not only the studied case but also any other ore, since it is based on the milling inner processes and the external classification. The studied magnesite process has currently four parallel ball mills operating in closed circuit with hydrocyclones, grinding the ore for the silicates flotation cells. The modification proposed changes the circuit to operate with three mills in open circuit with parameters that improves inner classification and particles transport and breakage. Their product are collected together to feed a high frequency screener, a more efficient equipment when compared to hydrocyclones. The screener oversize feeds a fourth ball mill to continue grinding and prepare the ore for the next steps, dewatering and reverse flotation. On the other hand, the screener undersize goes to desliming and reverse flotation equipment. According to the data collected in the pilot plant and the modeling for the industrial site, this modification could promote $27 \%$ increase in the productivity, due to $17.6 \%$ increase on mills feed and $7.8 \%$ in mass recovery, caused by loss reduction on desliming and flotation. The gain is expressive due to some inefficiency of the current circuit and still need to be validated on the industrial site.
\end{abstract}

Keywords: Grinding; Pilot plant; High frequency screen; Modeling; Magnesite.

\section{AUMENTO DA PRODUTIVIDADE EM UMA PLANTA PILOTO DE MAGNESITA COMBINANDO MOINHO DE BOLAS EM CIRCUITO ABERTO E PENEIRA DE ALTA FREQUÊNCIA}

\section{Resumo}

O circuito aberto e a peneira de alta frequência vêm sendo utilizados em circuitos de moagem, mas sem aproveitar seu inteiro potencial. Este trabalho apresenta uma nova abordagem, combinando-os com o objetivo de ter um uso mais eficiente da energia disponível e, assim, aumentando a produtividade. Este conceito poderia ser aplicado não só a este minério, mas a qualquer outro, uma vez que é baseado nos processos internos da moagem e na classificação externa. O processo de magnesita estudado possui quatro moinhos de bola operando em circuito fechado com hidrociclones, moendo o minério e preparando-o para as células de flotação de silicatos. A modificação proposta altera o circuito para operar com três moinhos em circuito aberto, com parâmetros que melhoram a classificação interna e também o transporte e quebra das partículas. Seus produtos seriam coletados e juntos enviados para alimentar uma peneira de alta frequência, equipamento de classificação mais eficiente que o hidrociclone. $O$ material retido na peneira alimentaria o quarto moinho para continuar a moagem e preparar o minério para os próximos estágios, desaguamento e então, flotação reversa. O passante da peneira, por outro lado, segue diretamente para deslamagem e flotação reversa. De acordo com os resultados obtidos na planta piloto e o modelamento do circuito industrial, esta modificação poderia aumentar a produtividade em $27 \%$, por possibilitar o aumento na alimentação da moagem em $17.6 \%$ e aumentar a recuperação mássica do circuito em $7.8 \%$, reduzindo as perdas na deslamagem e flotação. Estes resultados são expressivos devido a certa ineficiência do circuito atual e ainda precisam ser validados industrialmente.

Palavras-chave: Moagem; Planta piloto; Peneira de alta frequência; Modelamento; Magnesita.

'Centro de Pesquisas e Desenvolvimento, RHI Magnesita S.A, Contagem, MG, Brasil. E-mail: matheus.naves@magnesita.com

${ }^{2}$ Escola de Engenharia, Universidade Federal de Minas Gerais, Belo Horizonte, MG, Brasil.

2176-1523 (c) 2019 Associação Brasileira de Metalurgia, Materiais e Mineração. Published by ABM. This is an open access paper, published under the Creative Commons CC BY-NC-ND license (Attribution-NonCommercial-NoDerivs) - https://creativecommons.org/licenses/ by-nc-nd $/ 4.0 \%$ 


\section{INTRODUCTION}

Magnesite, apart from sea water magnesia, is the main feedstock for dead burned magnesia (DBM) production, one of the most important raw materials for basic refractories. $\mathrm{RHI}$ Magnesita is the most important DBM producer in Latin America, in its Brumado, Bahia State, Brazil, operation. The ore is extracted from an open pit mine named Pomba.

Despite having one of the purest magnesite reserves, silicates still must be removed from the Pomba ore, in order to achieve the desired DBM chemical composition. In order to do so, the ore has to be ground prior to reverse flotation, so the silicates can be separated from magnesite. This concentration is important to produce a high performance $\mathrm{DBM}$, and the magnesite is transformed into magnesia trough a double step firing in high temperature shaft kilns.

The current concentration process starts with an impact crusher, preparing the particle size distribution to feed the ball mills. The milling operation has four ball mills working in closed circuit with hydrocyclones. This conventional circuit promotes a high circulating load and overgrinding, thus reducing the selectivity in the following operations, desliming and flotation, which is detrimental to mass and metallurgical recoveries.

The recent Chinese environmental measures reduced the DBM availability in the market, since China is the key magnesia producer, pushing the prices up and the demand for other DBM sources. Given this scenario, the Brumado operation aims to increase the DBM production and the concentration process was identified as the bottleneck [I].

\section{MATERIALS AND METHODS}

Firstly, a review on grinding concepts was carried out to determine the milling parameters and draw up the pilot plant trials. Also, the comminution mathematical modeling was revisited to base the scale up procedure. Afterwards, the pilot plant tests were drawn up to meet the selected condition and the milling operation was modeled.

\section{I Milling Parameters}

An efficient milling takes advantage of the ore mineralogy and slurry rheology to promote a comminution with better energy application, improved inner classification and enhanced particles transportation, consequently, using less energy to liberate the ore [2].

The key parameters to carry out an efficient milling are solids percentage, media charge and circulating load. The optimal solids percentage is not too high that could be detrimental to internal classification and transportation and not too low that could decrease the probability of the particles to suffer media impact [3]. The media charge objective is to promote impact and transfer the energy supplied to the mill, and the filling should not be high enough to reduce the cascading height, which is unfavorable to the energy efficiency [4]. Another feature is the circuit type, open as compared to the closed circuit. Comparing the assessed process productivity, an open circuit shows more efficient grinding, since it reduces overgrinding and improves the subsequent operations [5].

However, to take advantage of these characteristics, the circuit must count on an efficient classification process. The high frequency screener, recently developed for industrial mining process, has been proving some advantages when compared to the traditional hydrocyclone for closed circuits [6].

Nevertheless, none of these works have combined the benefits of open circuit and high frequency screener to increase the circuit productivity.

\subsection{Milling Modeling}

The comminution modeling was performed using the population balance model, as reviewed by Mazzinghy and Alves $[7,8]$. The modeling is based on the specific parameters determination on both selection function and breakage function.

The selection function is determined by the parameterization of $\propto_{0}, \propto_{1}, \propto_{2}$ and $d_{\text {crit }}$, discribed by equation I [9]:

$$
S_{i}=\frac{\propto_{0} d_{i}^{\alpha_{1}}}{1+\left(\frac{d_{i}}{d_{c r i t}}\right)^{\alpha_{2}}} ; \quad i=1, \ldots, n
$$

On the other hand, the breakage function is modeled by the variables $\beta_{0}, \beta_{1}$ and $\beta_{2}$, showed by equation 2 [10]:

$$
B_{i j}=\beta_{0}\left(\frac{d_{i}}{d_{j}}\right)^{\beta_{1}}+\left(1-\beta_{0}\right)\left(\frac{d_{i}}{d_{j}}\right)^{\beta_{2}} ; \quad i=1, \ldots, n ; j \leq i
$$

Finally, these parameters must be associated to the available energy for comminution and the equipment size, as demonstrated by equations 3 and $4[11,12]$ :

$$
\begin{aligned}
& S_{i}=S_{i}^{E}\left(\frac{P}{H}\right) \\
& P_{\text {net }}=\eta P_{\text {gross }}=0,238 D^{3,5}\left(\frac{L}{D}\right) N_{c} \rho_{a p}\left(J-1,065 J^{2}\right) \sin \alpha
\end{aligned}
$$

Using these equations, it is possible to predict the particle size distribution given the feed particle size and the required mass rate.

\subsection{Milling Efficiency Comparison}

The Bond Efficiency was established to compare industrial circuits and has been used to measure industrial efficiency [13]. It compares the operational work index with 
the Bond work index, making possible to relate different operations on the same basis.

Equation 5 exhibits the efficiency calculation:

$$
\text { Bond Efficiency }(\%)=\frac{W i_{\text {Bond }}}{W i_{\text {Operational }}}
$$

Since the Bond work index is a standard test often used for mills sizing, if the operational work index is lower than the Bond value, the operation works is surpassing its designed conditions. Therefore, the higher the Bond efficiency the better is the process.

\subsection{Pilot Plant Design}

The pilot plant flowsheet was designed to simulate the proposed industrial circuit with equipment that is adequate to obtain the modeling parameters, especially for the comminution circuit.

Two tests were drawn up, the first one reproducing the first milling, with open circuit and selected conditions, to acquire parameters for modeling. In this same circuit, following the mill, a high frequency screen took place to carry out the classification. The screener undersize proceeded to desliming and flotation and the oversize was stored for the second test, simulating the secondary milling.
Since the secondary milling was never tested for this ore before and the operational work index was unknown, the primary milling conditions were used on the second pilot trial, in order to model this process; the desliming and flotation were performed in bench scale equipment with samples of the mill product.

Figure I displays the pilot plant flowsheet and Table I shows the pilot mill dimensions and the parameters chosen for the trials.

As mentioned before, the secondary milling behavior was uncertain. However, it was chosen to sustain the primary milling conditions and alter the necessary variables on the scale up, through simulation, in order to achieve the desired productivity and particle size distribution.

Considering the pilot plant designed and the parameters chosen, the trials were then carried out.

\subsection{Ore Characteristics}

The analyzed ore mineralogy is composed mainly by magnesite, talc, chlorite and quartz, identified by X-Ray Diffraction. The main contaminant for the product is $\mathrm{SiO}_{2}$ its concentration in the process feed is approximately $3 \%$ and it must reach less than $0.30 \%$ to achieve the specification, measured by X-Ray Fluorescence in calcined basis. The $\mathrm{MgO}$ content is also important; it has to be above

Pilot Plant Flowsheet

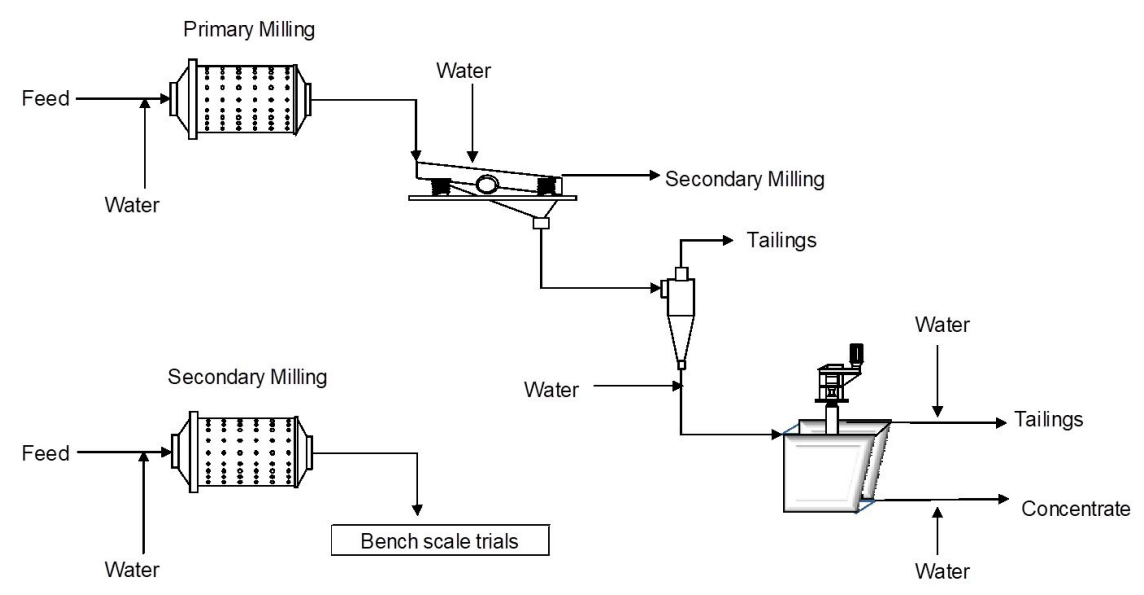

Figure I. Pilot plant trials flowsheet.

Table I. Pilot mill characteristics and selective parameters tested

\begin{tabular}{ccc}
\hline & Primary Milling & Secondary Milling \\
\hline Efective mill diameter $(\mathrm{m})$ & 0.59 & 0.59 \\
Efective mill lenght $(\mathrm{m})$ & 0.88 & 0.88 \\
Media charge (\%V) & 30.0 & 30.0 \\
Solids (\%w) & 55.0 & 55.0 \\
Critical speed (\%) & 80.0 & 80.0 \\
Feed rate (tph) & 0.59 & 0.51 \\
\hline
\end{tabular}


$98 \%$ in the concentrate, starting near to $96 \%$ on the feed using the same analytical methodology.

\subsection{Modeling Software}

The Moly-Cop Tools was used for milling modeling and simulation. This software was developed by a grinding media supplier (Moly-Cop) to aid its customers to improve their processes.

\section{RESULTS AND DISCUSSION}

\section{I Primary Milling Test, Modeling and Scale up}

The first evaluated condition concerned the primary milling, modeling the comminution process and analyzing desliming and flotation of the screener underflow. Table 2 shows the main modeled milling parameters and experimental particle size distribution obtained on pilot plant trial.

With these parameters the process was scaled up for the projected industrial site. The industrial circuit has four ball mills equally divided in two sizes and power, $184 \mathrm{~kW}$ and I I $0 \mathrm{~kW}$. Table 3 exhibits the predicted operation conditions compared to the current parameters. The current situation, for all comparisons, was modeled and simulated based on samples took on the circuit roughly at the same time as the sample for pilot plant trials was taken
As shown in table 3 , the milling capacity could be increased, using only three mills for primary grinding. However, the fourth mill must be used in the secondary milling, since $30 \%$ of the primary milling product is retained in the screener. These results agree with previous works $[5,14]$.

Another key benefit of these conditions is the overgrinding reduction, illustrated in Figure 2.

Since silica is the main contaminant, the analysis was focused on this component. The overground magnesite is picked up among the smaller particles, reducing the $\mathrm{SiO}_{2}$ content in these fractions. This is unfavorable for the process since energy was spent to grind unnecessarily these particles, so they will be lost in desliming, reducing the mass recovery and, consequently, productivity. This behavior was also observed for different ores [15].

\subsection{Secondary Milling Test, Modeling and Scale up}

The same procedure was adopted for the secondary milling, with the modeling parameters, experimental particle size distributions and hydrocyclone dimensions detailed in table 4.

From the primary milling simulation, the second step would be fed with 30 tph, therefore, the scale up was carried out to verify if the available mill could fit this demand. Table 5 illustrates the main characteristics of the secondary milling compared to pilot plant data.

To maintain the flotation selectivity, the secondary milling $\mathrm{P}_{80}$ could not exceed $2 \mathrm{I} 2 \mu \mathrm{m}$. In fact, the simulated

Table 2. Primary milling modeling parameters

\begin{tabular}{|c|c|c|c|}
\hline \multicolumn{4}{|c|}{ Primary Milling Modeling } \\
\hline \multicolumn{2}{|c|}{ Selection Function } & \multicolumn{2}{|c|}{ Breakage Function } \\
\hline$\alpha_{0}$ & 0.000006 & $\beta_{0}$ & 0.243 \\
\hline$\alpha_{1}$ & 1.955 & $\beta_{1}$ & 0.500 \\
\hline$\alpha_{2}$ & 2.500 & $\beta_{2}$ & 2.001 \\
\hline$d_{\text {crit }}$ & 9377 & & \\
\hline \multicolumn{2}{|c|}{ Mill Feed Particle Size Distribution } & \multicolumn{2}{|c|}{ Mill Discharge Particle Size Distribution } \\
\hline Particle Size $(\mu \mathrm{m})$ & Cumm. Passing (\%) & Particle Size $(\mu \mathrm{m})$ & Cumm. Passing (\%) \\
\hline 9500 & 100 & 9500 & 100 \\
\hline 6300 & 95.3 & 6300 & 100 \\
\hline 4000 & 85.8 & 4000 & 100 \\
\hline 2000 & 75.9 & 2000 & 100 \\
\hline 1000 & 69.5 & 1000 & 99.6 \\
\hline 850 & 66.6 & 850 & 99.2 \\
\hline 500 & 57.9 & 500 & 95.8 \\
\hline 425 & 54.2 & 425 & 93.5 \\
\hline 300 & 41.8 & 300 & 82.3 \\
\hline 212 & 30.7 & 212 & 66.5 \\
\hline 150 & 21.5 & 150 & 49.9 \\
\hline 106 & 15.5 & 106 & 37.4 \\
\hline 75 & II.I & 75 & 27.4 \\
\hline 63 & 9.63 & 63 & 23.8 \\
\hline 45 & 7.29 & 45 & 18.0 \\
\hline 38 & 6.52 & 38 & 16.0 \\
\hline
\end{tabular}


Table 3. Comparison between current and projected circuits

\begin{tabular}{|c|c|c|}
\hline \multirow{2}{*}{ Status } & \multicolumn{2}{|c|}{ Primary Milling } \\
\hline & Current & Project \\
\hline Number of Ball Mills & 4 & 3 \\
\hline Feed rate (tph) & 90 & 100 \\
\hline Circuit & Closed & Open \\
\hline Circulating Load (\%) & 700 & - \\
\hline $\mathrm{F}_{80}(\mu \mathrm{m})$ & 2693 & 2693 \\
\hline Avarage $P_{80}(\mu \mathrm{m})$ & 470 & 266 \\
\hline Avarage $\mathrm{Wi}_{\mathrm{o}}(\mathrm{kWh} / \mathrm{t})$ & 9.90 & 7.33 \\
\hline Grinding Media (\%V) & 40.0 & 30.0 \\
\hline Feed Solids Concentration (\%) & 75.0 & 55.0 \\
\hline Hydrocyclone Eficiency $(\%-212 \mu \mathrm{m})$ & 86.6 & - \\
\hline Average Bond Efficiency (\%) & 82.9 & 113.8 \\
\hline
\end{tabular}

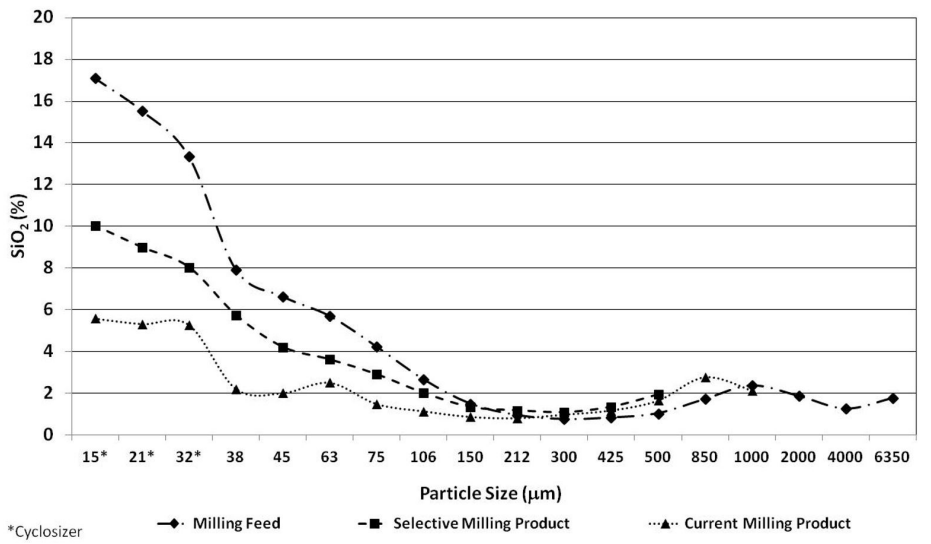

Figure 2. Chemical composition per particle size on milling process.

Table 4. Secondary milling modeling parameters

\begin{tabular}{|c|c|c|c|}
\hline \multicolumn{4}{|c|}{ Secondary Milling Modeling } \\
\hline \multicolumn{2}{|c|}{ Selection Function } & \multicolumn{2}{|c|}{ Breakage Function } \\
\hline$\alpha_{0}$ & 0.00013 & $\beta_{0}$ & 0.399 \\
\hline$\alpha_{1}$ & 1.419 & $\beta_{1}$ & 0.606 \\
\hline$\alpha_{2}$ & 3.130 & $\beta_{2}$ & 3.600 \\
\hline $\mathrm{d}_{\text {crit }}^{2}$ & 10629 & & \\
\hline \multicolumn{2}{|c|}{ Mill Feed Particle Size Distribution } & \multicolumn{2}{|c|}{ Mill Discharge Particle Size Distribution } \\
\hline Particle Size $(\mu \mathrm{m})$ & Cumm. Passing (\%) & Particle Size $(\mu \mathrm{m})$ & Cumm. Passing (\%) \\
\hline 4000 & 100 & 4000 & 100 \\
\hline 2000 & 99.6 & 2000 & 100 \\
\hline 1000 & 96.3 & 1000 & 99.9 \\
\hline 850 & 95.3 & 850 & 99.7 \\
\hline 500 & 71.9 & 500 & 96.4 \\
\hline 425 & 62.9 & 425 & 92.7 \\
\hline 300 & 31.1 & 300 & 78.4 \\
\hline 212 & 14.7 & 212 & 61.0 \\
\hline 150 & 8.03 & 150 & 45.7 \\
\hline 106 & 3.81 & 106 & 33.2 \\
\hline 75 & 2.25 & 75 & 24.8 \\
\hline 63 & 1.83 & 63 & 21.6 \\
\hline 45 & 1.45 & 45 & 17.1 \\
\hline 38 & 1.26 & 38 & 15.2 \\
\hline \multicolumn{4}{|c|}{ Hydrocyclone Dimentions (mm) } \\
\hline Quantity & 3 & Inlet & 6.35 \\
\hline Diameter & 25.4 & Vortex & 8.89 \\
\hline Height & 76.2 & Apex & 5.13 \\
\hline
\end{tabular}


secondary milling product fits within this specification, thus proving that the process is feasible.

Is this case, the closed circuit was chosen because the ore is homogeneous both in particle size and mineralogy, reducing milling efficiency and not justifying the investment in another high frequency screener. However, the reduced media charge and solids percentage were maintained, as they aid the inner classification and transport, therefore, increasing the milling efficiency as reported previously [16].

The pilot plant was carried out using open circuit since it is not possible to close circuit with hydrocyclones in this installation. The secondary simulation was carried out combining the pilot plant results and the current hydrocyclones modeling.

With the grinding circuit verified, the flotation was evaluated for both milling circuits.

\subsection{Flotation}

In order to simplify the nomenclature, the process undergone by the screener undersize was named primary milling circuit and that corresponding to the oversize, secondary milling circuit.

The primary milling product was analyzed in the pilot plant, verifying the consequences of different screen openings $(300 \mu \mathrm{m}$ and $212 \mu \mathrm{m})$ and the process recovery. On the other hand, the secondary milling product was analyzed in bench tests. Table 6 exhibits the results obtained.

Considering previous trials, this pilot plant can reproduce the flotation and desliming industrial performance. Hence, the results found in the pilot tests were expected to be reproduced on the industrial process, as shown in Table 6 .

Moreover, the screen opening must be carefully analyzed, given the $\mathrm{SiO}_{2}$ results obtained in the pilot tests. The concentrate generated from the $300 \mu \mathrm{m}$ screen undersize has $\mathrm{SiO}_{2}$ percentage higher than the accepted value $(0.30 \%)$, whereas the one produced from the $212 \mu \mathrm{m}$ screen undersize lies within the specification. This result is expected, since the mechanical reverse flotation presents inferior selectivity for coarse particles [17].

Finally, the secondary milling circuit desliming and flotation were evaluated. Nevertheless, these processes were analyzed only in bench scale tests, as the pilot plant does not have the necessary hydrocyclone to provide a closed milling circuit.

As a result, the secondary milling product was dried and screened in a $212 \mu \mathrm{m}$ sieve to produce the material for the tests. Afterwards, the desliming was performed in a $20 \mu \mathrm{m}$ sieve prior to flotation. The results of this procedure are in Table 7.

In this case, fewer fines particles were generated in the secondary milling. Hence, the desliming mass recovery was higher and yet the $\mathrm{SiO}_{2}$ percentage in the flotation concentrate fell far below the specification. As a matter of fact, in the industrial process the silica content should be higher, because a result this low could be detrimental
Table 5. Secondary milling simulation compared to pilot plant results

\begin{tabular}{lcc}
\hline \multirow{1}{*}{ Status } & \multicolumn{2}{c}{ Secondary Milling } \\
\cline { 2 - 3 } & Pilot Plant & Project \\
\hline Number of Ball Mills & $\mathrm{I}$ & $\mathrm{I}$ \\
Feed rate (tph) & $0.5 \mathrm{I}$ & 30 \\
Circuit & Open & Closed \\
Circulating Load $(\%)$ & - & 168 \\
$\mathrm{~F}_{80}(\mu \mathrm{m})$ & 612 & 678 \\
$\mathrm{P}_{80}(\mu \mathrm{m})$ & 315 & 202 \\
$\mathrm{Wi}_{\circ}(\mathrm{kWh} / \mathrm{t})$ & - & 14.6 \\
Grinding Media $(\% \mathrm{~V})$ & 30.0 & 30.0 \\
Feed Solids Concentration (\%) & 55.0 & 55.0 \\
Bond Efficiency $(\%)$ & - & 82.0 \\
\hline
\end{tabular}

Table 6. Primary milling desliming and flotation results

\begin{tabular}{lcc}
\hline \multicolumn{1}{c}{ Status } & \multicolumn{2}{c}{ Primary Milling } \\
\cline { 2 - 3 } & $\begin{array}{c}\text { Pilot Plant } \\
\text { Result }\end{array}$ & Project \\
\hline Feed rate (tph) & 0.29 & 70.0 \\
Desliming recovery (\%) & 90.9 & 90.9 \\
$\% \mathrm{SiO}_{2}(300 \mu \mathrm{m}$ Concentrate) & 0.40 & 0.40 \\
$\% \mathrm{SiO}_{2}(212 \mu \mathrm{m}$ Concentrate) & 0.28 & 0.28 \\
Flotation recovery - 2 I $2 \mu \mathrm{m}$ & 94.3 & 94.3 \\
Concentrate (\%) & & \\
Production (tph) & 0.25 & 59.6 \\
Mass recovery (\%) & 85.7 & 85.7 \\
\hline
\end{tabular}

Table 7. Secondary milling desliming and flotation results

\begin{tabular}{lcc}
\hline \multicolumn{1}{c}{ Status } & \multicolumn{2}{c}{ Secondary Milling } \\
\cline { 2 - 3 } & $\begin{array}{c}\text { Bench Scale } \\
\text { Result }\end{array}$ & Project \\
\hline Feed rate (tph) & - & 70.0 \\
Desliming recovery (\%) & 99.0 & 99.0 \\
$\% \mathrm{SiO}_{2}(212 \mu \mathrm{m}$ Concentrate) & 0.13 & 0.26 \\
Flotation recovery - 21 $2 \mu \mathrm{m}$ & 93.4 & 94.3 \\
Concentrate (\%) & & \\
Production (tph) & - & 59.6 \\
Mass recovery (\%) & 92.5 & 93.3 \\
\hline
\end{tabular}

to the subsequent processes. Therefore, for the designed operation the considered value of $\mathrm{SiO}_{2}$ was higher and, hence, the recovery would be increased.

\section{CURRENT AND DESIGNED PROCESSES COMPARISON}

In summary, Table 8 exhibits the comparison of the current process, using the conventional closed circuit mill, with the proposed selective milling process combining open circuit and high frequency screen.

As a result, the process modification could bring $17.6 \%$ increase in the feed capacity and $27 \%$ in the industrial productivity. The productivity raise is higher than the feed increase, as the desliming and flotation selectivity are improved 
Table 8. Summarized comparison of current and designed processes

\begin{tabular}{|c|c|c|c|c|c|}
\hline \multicolumn{2}{|c|}{ Current Process } & \multicolumn{4}{|c|}{ Designed Process } \\
\hline & Total & Primary Milling & Secondary Milling & Total & $\Delta(\%)$ \\
\hline Feed (tph) & 85.0 & 70.0 & 30.0 & 100 & +17.6 \\
\hline Desliming Recovery (\%) & 89.4 & 90.9 & 99.0 & 93.3 & +4.36 \\
\hline Flotation Recovery (\%) & 91.8 & 94.3 & 94.3 & 94.3 & +2.72 \\
\hline Mass Recovery (\%) & 81.2 & 85.7 & 93.3 & 87.6 & +7.88 \\
\hline Production (tph) & 69.0 & 59.6 & 28.0 & 87.6 & +27.0 \\
\hline
\end{tabular}

by the lower overground and a more homogenous ore feed, especially in the secondary milling route.

\section{CONCLUSIONS}

The present study introduces a new approach for milling circuits, combining open circuit and high frequency screen for classification. These results were found for this particular ore; nevertheless, it could be applied to other ores composed by minerals with different behavior under milling.

The desired increase in productivity could be achieved with the current mills, acquiring only a high frequency screener. For that, three mills must be altered to open circuit, using parameters that improve the grinding inner processes, and their products must be fed into the high frequency screener. The screener undersize goes directly to desliming and flotation. The screen oversize, on the contrary, follows to a secondary milling, then to desliming and flotation. A closed circuit with hydrocyclones was considered for the secondary milling.

The milling parameters that allowed the process improvement were lower media charge (30\%) and reduced solids percentage ( $55 \%)$, thus enhancing the inner classification and the transport in the mill.

Desliming and flotation test in pilot plant and bench scale confirmed the process feasibility and the benefits of the selective milling for the subsequent operations, as well.

As a result, the productivity could be increased by $27 \%$ and the mass recovery is expected to raise $7.8 \%$.

Since these results were obtained from pilot and bench scale trials, they still must be validated in the industrial installation. Moreover, all trials used magnesite as feedstock and the benefit for other ores needs to be tested.

\section{Acknowledgements}

The authors are thankful to Nivaldo César, Gleiber Assis, Gustavo Nogueira e Roberto Galery for their contribution to this work. The authors are also grateful to the following institutions and offices: the Federal University of Minas Gerais (UFMG), the Post-Graduate Program in Metallurgical, Materials and Mining Engineering (PPGEM) and to CAPES/PROEX. The co-author P.R.G. Brandão also acknowledges $\mathrm{CNPq}$ for a research grant.

\section{REFERENCES}

I Li A. Chinese magnesia industry must meet new standards or face shutdown. Industrial Minerals. 2017 [cited 2017 July 07];595. Available at: http://www.indmin.com/Article/373।483/Issue/98। I I/Chinese-magnesia-industry-mustmeet-new-standards-or-face-shutdown.html

2 Yovanovic AP. Comminution engineering and grinding in tubular mills (Portuguese). MOPE: Belo Horizonte; 2004.

3 Tangsathitkulchai $\mathrm{C}$. The effect of slurry rheology on fine grinding in a laboratory ball mill. International Journal of Mineral Processing. 2003;69:29-47.

4 Deniz V. The effects of ball filling and ball diameter on kinetic breakage parameters of barite powder. Advanced Powder Technology. 2012;23:640-646.

5 Singh N, Beaudoin R, Lebeuf, Farsangi, MC, Dumais, A. Debottlenecking the primary grinding circuit of the Nunavik nickel project. In: International Mineral Processing Congress. Proceedings of the 28th International Mineral Processing Congress; 2016, September II-15; Quebec City, Canada: IMPC; 2016. p. 19.

6 Barkhuysen NJ. Implementing strategies to improve mill capacity and efficiency through classification by particle size only, with case studies. In: The South African Institute of Mining and Metallurgy. Proceedings of the 5th Southern African Base Metals Conference; 2009; Kasane, Botswana. Kasane: The South African Institute of Mining and Metallurgy; 2009. p. I0I-II4.

7 Mazzinghy DB. Modeling and simulation of a grinding circuit through breakage and specific energy parameters determination (Portuguese). [master dissertation]. Belo Horizonte: Universidade Federal de Minas Gerais; 2009. 
8 Alves VK. Grinding media optimization using mathematical modeling and grinding simulation tools (Portuguese). [master dissertation]. Belo Horizonte: Universidade Federal de Minas Gerais; 2006.

9 Austin LG, Klimpel RR, Luckie PT. Process engineering of size reduction: ball milling. New York: SME AIME; 1984.

10 Austin L, Shoji K, Bhatia V, Jindal V, Savage K, Klimpel R. Some results on the description of size reduction as a rate process in various mills. Industrial \& Engineering Chemistry. 1976; 15: I87- 196.

I I Herbst, JA, Fuerstenau, DW. Scale-up procedure for continuous grinding mill design using population balance models. International Journal of Mineral Processing. 1980;7:0I-3I.

12 Hogg R, Fuerstenau DW. Power relationships for tumbling mills. SME-AIME Transactions. 1972;252:4 I8-423

13 Mclvor RE. The GMSG guideline for determining the bond efficiency of industrial grinding circuits. In: International Mineral Processing Congress. Proceedings of the 28th International Mineral Processing Congress; 2016 September II-I5; Quebec City, Canada: IMPC; 2016. p. 17.

I4 Forsund B, Norkyn I, Sandvik KL, Winther K. Sydvarangers 6,5m diameter x 9,65m ball mills. In: International Mineral Processing Congress. Proceedings of 16th International Mineral Processing Congress; 1988 June 5- I0; Stockholm, Sweden. Amsterdam: Elsevier Science Publishers BV; 1988. p. I7I-I83.

15 Von Reeken FJM, Lange J, Steensma JJS, Duyvesteyn WPC. Factors affecting the lead-zinc separation at the ground concentrator. International Journal of Mineral Processing. 1989;27:21-37.

16 Makokha AB, Madara DS, Namago SS, Ataro E. Effect of slurry solids concentration and ball Loading on mill residence time distribution. International Journal of Mining Engineering and Mineral Processing. 2014;3:2I-27.

17 Jameson GJ. The effect of surface liberation and particle size on flotation rate constants. Minerals Engineering. 2012;36-38:132-137.

Received: 4 Out. 2017

Accepted: 2 Fev. 2018 